\title{
Ukrainian Popular Science in Habsburg Galicia, 1900-141
}

\author{
Martin Rohde \\ University of Innsbruck
}

\begin{abstract}
This paper historicizes the idea of "popular science" in the Ukrainian academic discourse in relation to contemporary approaches to "national science" (as "science proper") and places special emphasis on the introduction of regular scientific lectures to public audiences in early twentieth century Habsburg Galicia. The Shevchenko Scientific Society was the central Ukrainian association of scholars and scientists at the time. Male-dominated, and increasingly dedicated to "Ukrainoznavstvo" ("Ukrainian studies"), the Shevchenko Scientific Society paid little attention to the popularization of scientific research. The Petro Mohyla Society for Ukrainian Scientific Lectures emerged in reaction to the Shevchenko Society. Its goal was to expand public awareness of the scientific work, and its members proceeded to organize regular public lectures all over Galicia between 1909 and 1914. This paper analyzes such popularization of science, propagated by the Petro Mohyla Society, and examines the lecture audiences with regard to their location, gender, and respective interests.
\end{abstract}

Keywords: Ukrainian history, history of science, Ukrainoznavstvo, popular science, Shevchenko Scientific Society.

The early twentieth century saw an immense transformation in the modes of science communication all over Europe. This was closely related to the defining and redefining of the role of science for the public. However, aspects such as space, ${ }^{2}$ language, and political context were crucial categories for different ideas about public science and education. To understand the acceptance and use of science by the public, every case has to be historicized. The manifold history of the Ukrainian national movement ${ }^{3}$ and its educational projects in Habsburg Galicia has been the

1 This paper was supported by the Center for Urban History of East Central Europe in Lviv and the Tyrolean Science Fund. I am thankful to Jamie Freeman, Stefan Hechl, and Marina Hilber for their tremendous help with this paper's language. I also thank the discussants at the Urban Seminar and the anonymous peer reviewers for their helpful comments. All translations in this article are my own.

2 By space I mean administrative territories, cultural spaces, and spaces of "circulation" of knowledge (Raj).

3 With respect to the constructed character of nations (Anderson) and the recent critical studies on national indifference, "nation" is not considered to be a static 
subject of many recent works. Yet, the popularization of scientific knowledge still awaits its researcher.

National struggles in the Habsburg Empire were not only the result of national activism, they were also a result of language and ethnic categories introduced by the state (Stergar and Scheer). Often, these struggles were located around "institutional spaces . . . created by the empire" (Judson, Habsburg 6). Activists translated language struggles into national issues (Judson, Guardians). In the Ukrainian case, this concerned schools as well as universities during the late nineteenth and early twentieth centuries because the Galician education system had largely been dominated by Polish elites since the late 1860s. ${ }^{4}$ While the educational institutions have been the subject of many recent works, less effort is devoted to research concerning alternative national associations, who positioned their initiatives as substitutes for the lacunas in the work of established national institutions in Galicia.

Since its reorganization as an informal academy of sciences in 1892, the Shevchenko Scientific Society ("Naukove Tovarystvo im. Shevchenka"; NTSh) has served as a nucleus for the Ukrainian scientific community. ${ }^{5}$ As I will point out, the majority of the Galician-Ukrainian intelligentsia ${ }^{6}$ considered the NTSh to be responsible for popularizing science. The NTSh is justifiably treated as an integral part of the national movement, but its relation to the state, to the public, and to other organizations, and the interrelations between these, have not been sufficiently researched. Such

historical category; it is a category of self-identification of the narrow groups under consideration (Zahra, "Imagined"). When I refer to the "Ukrainian community," I mean here Ukrainian national associations, their members, and the visitors to their events. Conservative Ruthenians or Russophiles are not included in this term. Russophiles were dominant in Galicia well into the 1890s. On the Russophile society for (popular) education, the Kachkovs'kyi Society, see Wendland 262-321.

4 Only during the 1890s did Ukrainian politicians enable the founding of a second Ukrainian gymnasium (academic high school) and initiate instruction of the Ukrainian language in other schools (Pakholkiv).

5 The early NTSh was comprised of conservative Ukrainian intelligentsia (Rohde, "Galizische"). I reflect on the NTSh membership in greater detail in "Nationale Wissenschaft.' For the tremendous wealth of Ukrainian literature on the subject, see Zaitseva; Vynar; Kachmar for further references.

6 "Intelihentsiia," "inteligentsiia" in vernacular Ukrainian. The groups associated with this term were fairly heterogeneous and therefore have to be considered in their regional contexts (Gordin and Hall). For an overview of pre-World-War-I European intelligentsia, see Sdvižkov. As a category of self-description in Galicia, the city-based Ukrainian intelligentsia considered themselves national elites and, close to the concept of organic work, defined themselves through the mission of educating peasants and raising the "cultural level" of the nation. 
relationships are especially intertwined in the popular communication of science. This article is a case study in which these relationships are mapped, and Ukrainian national popular science is placed in a transnational, imperial context.

Similar to Czech and Polish national projects in the Habsburg Empire, the NTSh concentrated its resources on the development of the humanities and even marginalized natural scientists in several ways (Surman, "Science"). Furthermore, the Ukrainian scientific community, and members of the NTSh in particular, were predominantly male. It was not until the interwar period that the number of women in the NTSh increased, and took not only supportive roles but also performed scholarly tasks (Diadiuk). Recent studies have emphasized the strong and influential Ukrainian feminist movement in Galicia and the interest of this movement in higher education. ${ }^{7}$ By reflecting on popular science in the Galician context, I examine the introduction of popular scientific lectures presented in the Ukrainian language, and describe how different approaches to popular science contributed to the building of (national) communities. This paper considers the central actors of the Ukrainian scientific community in Galicia, their conception of Ukrainian (popular) science and its audiences, the popularized subjects, the interest groups, and the gender of the audiences. I argue for a more diverse understanding of the "popularization" of science. It was not a mere elite project, but a reaction to public demand, and it was extremely responsive to criticism and to decreasing numbers of visitors. Thus, this paper contributes to the history of the Ukrainian intelligentsia in Galicia, its diversification, and its approach to common Central European issues during the early twentieth century.

\section{POPULAR SCIENCE IN IMPERIAL AND NATIONAL CONTEXTS}

Disciplines disseminate knowledge mainly through their respective handbooks, journals, private exchanges, and through semi-public meetings such as conferences or sessions in specific societies. The NTSh, with its various sections and expert commissions, is an example of an institution longing for the professionalization of several disciplines in the Ukrainian

\footnotetext{
7 Since 1897, women have been allowed to enroll as students in two faculties of Lviv University (Blahyi). Around the turn of the century, Ukrainian female associations multiplied and became more diverse (see Cherchovych; LeszczawskiSchwerk; Bohachevs'ka-Khomiak).
} 
language. ${ }^{8}$ Outside these narrow academic circles, there are "more or less educated dilettantes," who may or may not be interested in science (Fleck 149-50). The minimal definition of popular science is the process of communication between these groups. But this is more complex than a simple top-down relationship. One reason for this is the need to adjust scientific matters to public demands through the simplification of language and narratives (Fleck 150-51). Scholars' interactions with the general public were of special importance, as these interactions could inspire individuals to take part in citizen science enterprises or to pursue academic careers, objectives highly relevant to the formation of scientific communities (Bensaude-Vincent 363-64). In addition, there were huge differences between monolingual and multilingual contexts, as languages and their functions in science were usually organized hierarchically. ${ }^{9}$

In many regions and national communities, the initiation of popular science was related to the "scientification of the social" (Raphael) and/or the "scientification of the nation" (Weichlein 279). Therefore, popular science has been related to social and cultural struggles, where it has served as a tool of "mediation between public and experts" (Broks 143). The questions "what is expert science?" "who may serve as a mediator?" "what should be mediated and who are the (lay) public?" are not selfexplanatory. These aspects were fluid in discursive communities in the late nineteenth and early twentieth centuries, and are fluid today. They should therefore not be treated as stable, analytical categories, but as subjects of analysis (Bensaude-Vincent 365-66; Topham, "Introduction" 312-13). Consequently, popular science has to be analyzed in its specific contexts of space and time. Critical studies of popular science allow us to see spaces and communities through the prism of science by locating the role of science in popular culture, and by considering the public agency in science (Topham, "Introduction" 311). Finally, spaces of knowledge circulation influenced not only research itself, but also the social environment that generated necessary conditions for the production and circulation of knowledge.

The establishment of regular lectures for public audiences in the Habsburg Empire was inspired by the activities of the University of Vienna, as the Cisleithanian crown lands belonged to the same educational system as the imperial centre. British university extensions served as a model to establish popular scientific courses in Vienna in the late 1890s. Supported by the Ministry for Culture and Education in both symbolic and financial

8 The archaeographic commission is one example of a commission dedicated to the tasks of institutionalizing Ukrainian historical research and the training of students, with Mykhailo Hrushevs'kyi as the instructor (see Tel'vak and Pedych).

9 For the Habsburg Empire, see Surman, "Imperial Knowledge?"; Ash and Surman. 
terms, these enterprises extended the mission, meaning, and reputation of the university. The large numbers of attendants in the courses helped to create a sense of community through shared knowledge (Stifter, "Universität, Volksbildung und Moderne"). The impulse came from within the university and was related to a social phenomenon very common in the Cisleithanian academic landscape: the "Privatdozenten" ("private lecturers"). ${ }^{10}$ For them, the university extension programs provided a vehicle through which to ensure the relevance of their work, a market for their publications, and improvement in their economic situations. This model gradually expanded to other university cities in the Habsburg monarchy (Stifter, "Universität, Volksbildung und Moderne"). The universities in Cracow and Lviv, however, did not launch similar programs with direct state support. In 1897, a circle in the Polish Towarzystwo Szkoły Ludowej (The People's School Society) carried out public lectures and, in the following year, formed the Towarzystwo "Uniwersytet Ludowy" im. Adama Mickiewicza (Adam Mickiewicz Society "People's University") in cooperation with the University of Cracow. The organization, explicitly inspired by the university extension programs, conducted lectures in several Galician cities, and also founded a branch in Lviv in March 1899.11 Meanwhile in Vienna, the nexus between public education and nationalism did not manifest itself until the beginning of World War I. Until this point, national neutrality was considered to be the best route in Viennese science communication (Taschwer), but the language situation in Lviv set the basis for a different scenario. At the turn of the century, there was as yet no Ukrainian alternative to Uniwersytet Ludowy. While it is noteworthy that the Ukrainian social democrat Mykola Hankevych (1867-1931) was a founding member of its branch in Lviv, ${ }^{12}$ lectures in Ukrainian or on Ukrainian topics were not part of the program. Furthermore, neither members of the Shevchenko Scientific Society nor Ukrainian professors from Lviv University took part in the project. Although Uniwersytet Ludowy

10 These academics had already been habilitated and were allowed to lecture, but had low incomes compared to full professors. For "Privatdozenten" to become professors, the Austrian system intended that the respective faculty suggest a candidate to the Ministry for Culture and Education, which the latter had to approve. This led to a high number of qualified individuals looking for additional income in university cities (Taschwer). For more information on "Privatdozenten" in the various university cities of the Habsburg Monarchy, see Surman, Habsburg Universities.

11 See Wiedza dla Wszystkich, no. 1, 1899, p. 32.

12 Wiedza dla Wszystkich, vol. 1, 1899, p. 34. Hankevych is discussed in Strel'byts'ka. Hankevych also taught the Ukrainian summer courses in 1904, which shows his mobility between two national milieus. 
proposed the dissemination of "knowledge for all,"13 the framework was largely national in terms of personnel and language.

Nevertheless, public education was an integral part of the RuthenianUkrainian "narodovtsi"'s ("populists") national program. During the 1860s, Polish positivists coined the term "organic work" ("praca organiczna"), which denoted the strengthening of the nation's economic and cultural potential through education. Following the Austro-Hungarian Compromise of 1867, the liberal politics of the Habsburg state had allowed for the establishment of various institutions, and even supported them financially (Janowski, Polish). The approach of the "narodovtsi," developed based on the Polish example with strong emphasis on the countryside, was represented by the society Prosvita (Enlightenment). Prosvita was founded in 1868 to promote literacy and temperance, and expand agricultural and economic knowledge. Prosvita contributed greatly to the promotion of national culture, especially the cult of the Ukrainian national poet Taras Shevchenko (Liusniak 5; Pashuk). Printed books and brochures, calendars, and other periodicals were important tools to disseminate knowledge on these subjects. Most of the relevant Ukrainian scholars were located in Lviv or-in the case of middle school teachers-in another city. Therefore, communication with villagers had to be organized from afar. The growing network of Prosvita branches in towns and reading halls in villages made the national movement more accessible to people in the countryside. The reading halls received recent newspapers and spread information about political events relevant to national matters, such as elections or the census (Rohde, "Local”).

The compact city space of Lviv was filled with a dense network of societies, periodicals, state institutions, and, above all, universities and other educational projects (Binder, "Das ruthenische Pressewesen"; Janowski, "Galizien"; Pakholkiv). This resulted in a high concentration of scholars and scientists ready to share their knowledge, and a variety of different audiences that could be addressed and integrated into scientific communities. Since the beginning of the twentieth century, associations and representatives of the influential Ukrainian National-Democratic Party (UNDP) had publicly demanded the popularization of science in the Ukrainian language. As Prosvita was primarily occupied with other matters and the NTSh contained the most academics of Ukrainian national orientation, it seemed obvious for these groups to address the request to the NTSh. Furthermore, as the NTSh was the Ukrainian private organization with the highest level of financial support from the Ministry of Education

13 Translation of the title of the Wiedza dla Wszystkich journal; emphasis added. 
and the Galician administration, its agenda was considered a matter of public interest (Rohde, "Galizische").

In terms of gender, it is usually the male organizations that are highlighted when Ukrainian projects are discussed, particularly projects involving a university in Galicia with ambitions to diversify the scholarly/scientific landscape (Mudryi; Kachmar). However, feminist interest groups showed equal interest in higher education outside of the university. In their 1901 bylaws, the Kruzhok ukrains'kykh divchat (Circle of Ukrainian Girls) formulated the goals to become the centre for "scientific and social life" for Ukrainian girls and to organize projects that would support their education. To realize these goals, they planned to sustain a library and a reading room and to organize scientific lectures, literary readings, and other cultural events (Statut tovarystva 1-2). The Kruzhok considered itself much more democratic, dynamic, and "revolutionary" in its views than other Ukrainian women's associations, such as the Kliub rusynok (Club of Ruthenian Women) formed by their traditionalist mothers. ${ }^{14}$ This self-image was underscored by their comparatively early choice of the ethnonym "Ukrainian" over "Ruthenian."15

From the outset, the Kruzhok took a clear position against existing academic networks in Lviv, and characterized their relationship with their male peers in the following excerpt from the verses published in Dilo (The Deed):

Миж [sic] не підем на пораду

В “академіків" громади,

Бо сказали би нам в очі

Що з нас кожна замуж хоче .... .

We won't turn for advice

To the "academic" community

Because they'd say to our face

That every one of us wants to get married ....

Since the Kruzhok opposed Polish education, they wanted to expand their options for Ukrainian education, but without being "treated like geese." 16 In this way, they underlined the intersectionality of "being female"

\footnotetext{
14 Nova Khata, vol. 15, no. 5, 1939, p. 2.

15 For a brief discussion of the usage of this ethnonym, see Rohde, "Galizische."

16 Nova Khata, vol. 15, no. 5, 1939, p. 3. By the "'academic' community" they meant the students' organization "akademichna hromada," which was close to the NTSh; the quotation marks suggest the Kruzhok's reciprocally sarcastic attitudes toward the male students of the "akademichna hromada."
} 
and "being Ukrainian" in Galicia. ${ }^{17}$ The rapid growth of the Circle showed the relevance of these goals in Ukrainian society in Lviv in the early 1900s. ${ }^{18}$ By the end of 1903, the Circle had organized a series of public lectures and had earned the respect of the local press for their responsiveness to current issues. ${ }^{19}$ Their efforts were not limited to Circle projects, as several members also taught illiterate people (LeszczawskiSchwerk 135).

On February 12, 1904, the Kruzhok held a well-received public meeting attended by more than two hundred girls and "older" (not defined) visitors, during which questions of female organization and education were discussed. Here, as on other occasions, leading members, such as Dariia Shukhevych (1881-1941), gave talks on women's rights. A practical result of the event was the organization of "Ukrainian popular-scientific university lectures," events with extremely low entrance fees and high attendance. The general accessibility of the lectures supported another point valued by the Circle: class equality in terms of education. This point was also manifested in other aspects of the Circle's activities (LeszczawskiSchwerk 135-36). Several lecturers from the NTSh-such as Oleksandr Kolessa (1867-1945), Stepan Rudnyts'kyi (1877-1937), and Ivan Rakovs'kyi (1874-1949)-took part in these meetings. As the abovementioned individuals were also leading members of the Mohyla Society, there might have been some correlation between these enterprises. It is also possible that there was a direct relation between the Mohyla Society and the summer courses launched in June 1904, which are discussed below. ${ }^{20}$ Without going into further detail on the activities of the Kruzhok, for which available sources are limited, it is clear that these (young) women had a considerable interest in obtaining a higher education provided in their native language, as well as the agency to change the status quo.

17 Their young age should also be considered, as they did not fit in the traditional schemes of their mothers' work for the society; however, they were not discriminated because of their age. For a discussion of Ukrainian women in Galicia from a post-colonial perspective, see Cherchovych.

1830 members took part in the inaugural session; at the end of the year there were 96 members. A report in 1904-a few months after the successful public sessionshowed a further growth of 52 members, but the timespan is not defined. Nova Khata, vol. 15, no. 6, 1939, p. 2; nos. 7-8, p. 7.

19 See Dilo, 15 Nov. 1903, p. 3.

20 This is implied by a letter written by Ivan Franko, which pointed out that "youth" came up with the idea (Franko, Zibrannia tvoriv 241). In contrast, Hrushevs'kyi stated that the idea was brought up by somebody from Russian Ukraine (Kotenko). 


\section{THE NTSH AND POPULAR SCIENCE}

NTSh leadership and representatives of the Ukrainian community in Galicia were in disagreement about the aims of the Ukrainian national movement, and this included the goals and tasks of science. President Mykhailo Hrushevs'kyi (1866-1934) presented his idea of the historical mission of Ukrainians in Galicia in the famous brochure Nasha polityka (Our Politics): "Galician-Ukrainian politics, parliamentarian and social, are very important for the general development of Ukrainian life. Their meaning goes far beyond the border of solely political interests of Galicia ..." (25). This maxim set the tone for the orientation of the NTSh, which he wanted to be the transimperial centre of Ukrainian science proper. A statute project issued in 1903 demanded the introduction of regular popular scientific activities. It was proposed in opposition to Hrushevs'kyi's idea of doing national science without taking public interest into account. This opposition was comprised of university professors Stanislav Dnistrians'kyi (1870-1935) and Oleksandr Kolessa, conservative "narodovtsi," several school teachers, and other NTSh members who supported the Ukrainian National-Democratic Party (UNDP) and the ideals of "organic work." 21 The NTSh leadership dismissed the project with great political effort, marking one of the most intense crises in the society's history. In the following years, the matter was subject to several conflicts.

Most Galician-Ukrainian politicians, especially representatives of the UNDP, some of them also members of the NTSh opposition, favoured a focus on inner-Galician developments. V'iacheslav Budzynovs'kyi (1868-1935), editor of the UNDP journal Svoboda (Freedom), presented a view that radically opposed that of Hrushevs'kyi in a brochure in 1905. According to Budzynovs'kyi's critique, the NTSh should "spare all the strength, time and money" invested in the publication of scientific works, which "no Ruthenian reads or will ever read" (Zubryts'kyi 72). In Budzynovs'kyi's view, NTSh science served science only. Regarding organic work, Budzynovs'kyi considered only works dedicated to pedagogic matters or to administrative and political affairs to be useful; "[a]ny other scientific work would be nothing but a national disgrace at the moment" (Zubryts'kyi 72). The idea of Ukrainian science articulated by the NTSh leadership in response was addressed to an international scientific community, which it believed should recognize Ukrainians as a cultural nation, and more generally as a group with an identity separate from Polish or Russian factions (Rohde, 'Nationale Wissenschaft' 131-48). These issues of proving intellectual as well as linguistic "maturity" and national individuality by representing

21 Statute project 1903, TsDIAL, f. 309, op. 1, spr. 5. 
issues of science proper were central to the understanding of Ukrainian "national science" in the NTSh. Apart from popular brochures provided by individuals, popular communication of science was not on the agenda of the NTSh, even though there were clear demands for this from several sides. Ivan Franko (1856-1916) considered other Ukrainian organizations responsible for these matters. He referred here to the Prosvita, or the Rus'ke tovarystvo pedahohichne (Ruthenian Pedagogical Society) (Franko, "Deshcho"). However, while these associations were certainly interested in popularizing science, they had other focuses and no capacity to pursue this goal themselves. So, they referred the task to professional scholars/scientists. But the popularization of science was not on the NTSh agenda, as might be seen from the activity of the NTSh museum, which was dedicated to scientific collections and research rather than to public interaction (Kushnir). The only exceptions were summer courses held in 1904, which provoked mixed reviews.

\section{SUMMER COURSES 1904}

In early 1904, during an NTSh session, one of the ideas that came up was to organize summer courses during the academic break in Russia. ${ }^{22}$ The summer courses were organized hastily and took place in Lviv from the end of June to the end of July in 1904. To realize this project-which was comparable to a modern summer school, an emerging academic program in Europe around 1900-the organizers made tremendous efforts to avoid causing political chaos, similar to the chaos that occurred in Innsbruck in 1903 (Rohde, "Innerimperiale" 191-94). Formally, it was the Tovarystvo prykhyl'nykiv ukrains'koi nauky, literatury i shtuky (Society of Adherents of Ukrainian Science, Literature and Arts), and not the NTSh, that was responsible for the organization of the courses. Hrushevs'kyi used the Tovarystvo prykhyl'nykiv to circumvent his opposition and to introduce a teaching schedule suited to his understanding of science. ${ }^{23}$ The program

22 Franko, Zibrannia tvoriv 242. The respective minutes do not refer to such a proposal, but this is not surprising as the executive committee usually edited the minutes before fixing them in the respective books. Cf. protocols of the general sessions, TsDIAL, f. 309, op. 1, spr. 31, and the sessions of the executive committee, TsDIAL, f. 309, op. 1, spr. 34 .

23 The organizational committee was comprised of the NTSh's executive committee loyal to Hrushevs'kyi-Franko and the secretary Volodymyr Hnatiuk (18711926)—and his wife Mariia Hrushevs'ka (1868-1948). Furthermore, every lecturer except Mykola Hankevych was a "real member" ("diisnyi chlen") of the NTSh. The summer school was sponsored by Ievhen Chykalenko (1861-1929), a patron of 
was summarized as being primarily dedicated to the "history, history of literature, and ethnography." 24 It was rounded off with a Ukrainian language course for visitors from Russian Ukraine and Rakovs'kyi's lectures on evolutionary biology. ${ }^{25}$ Rakovs'kyi's lectures were the only sessions based on the natural sciences, and they were comparatively short, with only six hours allocated during the whole month of the courses. Nonetheless, the focus was on "Ukrainoznavstvo" ("Ukrainian studies"). ${ }^{26}$ As Hrushevs'kyi did not explain the concept behind the term until 1914, it was understood, literally, as studies of Ukraine. ${ }^{27}$ This is the first time he introduced this new term for NTSh's "national science" to a broad audience.

According to the official numbers, the event brought 135 participants and 11 lecturers and organizers together. Roughly a third of them were women. ${ }^{28}$ As there is no preserved list of members of the Kruzhok ukrains'kykh divchat, the number of affiliated participants cannot be estimated. However, leading members took part in the lectures and even organized afternoon activities for visitors from outside Lviv. ${ }^{29}$ It can be assumed the Kruzhok functioned as multipliers of knowledge by spreading the news about the courses to attract more female visitors. A considerable number of the attendants were citizens of the Russian Empire. Roughly a dozen of these travelled to Galicia to attend the summer courses, while several other visitors belonged to the emigrant community studying in Lviv (Rode, "Naukovi"). Precisely because of this fact, the event became a site of "transimperial" knowledge exchange and community building. As shown by

several Ukrainian projects from Odesa (DALO, f. 298, op. 1, spr. 9, ark. 2 zv.; Rohde, "Innerimperiale").

24 LNV, vol. VII, no. VIII, 1904, p. 105.

25 On Rakovs'kyi and the popularization of evolutionary theories, see the section on popular nationalism below.

26 LNV, vol. VII, no. VIII, 1904, pp. 111-12.

27 In 1914, Hrushevs'kyi described it as follows: "The concept 'Ukrainoznavstvo' [original: Ukrainovedenie-M. R.], as studies of the past and present of the Ukrainian people, their attributes and specifics, their territory and different conditions, which influenced life and development, could take shape only gradually and primarily throughout the last century" (Grushevskii 1). For a historical treatment of the discipline, cf. Homotiuk; however, this work has to be evaluated critically, as the author draws many aspects of historical sciences into consideration before any term or concept behind it was coined.

$28 L N V$, vol. VII, no. VIII, 1904, p. 113. Assuming the preserved identity cards of the participants are complete, the number was a little lower; see TsDIAL, f. 309, op. 2, spr. 206.

29 TsDIAL, f. 309, op. 2, spr. 206, ark. 1, 2. The efforts of Dariia Shukhevych and Nastia Hrinchenko need to be highlighted. On Hrinchenko, see Rode, "Naukovi." 
Anton Kotenko, the courses thereby served as a vehicle to bring the Ukrainian territories closer together.

The overall attendance of the summer school lectures was considered disappointing by the organizers. Hrushevs'kyi tried to attribute the low attendance to the scholarly level of the courses; it was considered that the courses were too academic and that the program of lectures was too packed. ${ }^{30}$ Volodymyr Doroshenko (1879-1963), a visitor from Russian Ukraine, argued differently. He pointed out that the actual interaction with Ukrainian cultural life in Lviv was not part of the program, even though this would have been particularly interesting to guests from Russian Ukrainian territories. He added that several lecturers, including Hrushevs'kyi, simply had a boring style of teaching. Doroshenko was otherwise positively impressed by the other lecturers and by the private contact with Franko and the anthropologist Fedir Vovk (1847-1918). Franko regularly sat down in a coffee house with visiting attendants and invited guests from Russian Ukraine to live in his home, while Vovk took several walks through the city with some of the students, walks that were both enjoyable as well as intellectually stimulating (Doroshenko, "Ivan Franko v moikh"; Doroshenko, "'Ivan Franko"). In 1909, Doroshenko emigrated to Lviv and served the NTSh for more than fifty years (Suproniuk). On the one hand, this is an important contextualization of Doroshenko's statements on the courses, as they were his first acquaintance with the NTSh. On the other hand, his case shows how popular science can influence the building of scientific communities. ${ }^{31}$

The summer courses in Galicia, organised by the Society of Adherents of Ukrainian Science, Literature and Arts, in 1904, were an important landmark for several reasons. First, they were open to female and nonUkrainian audiences. ${ }^{32}$ Despite the criticism, the organizers and the financier, Ievhen Chykalenko, considered the courses to be a success. One can argue that it is surprising that the Ukrainian summer courses were not continued by the NTSh, despite the decision to hold follow-up courses the

\footnotetext{
30 LNV, vol. VII, no. VIII, 1904, pp. 102-113.

31 On the NTSh and scientific community building, see Rohde, "Local."

32 There was no formal nationality restriction, but, of course, the Ukrainian language of instruction limited the circle of interested parties. Actually, the only non-Ukrainian participant was Salomea Perlmutter, a socialist who usually wrote in Polish and was active in the Polish cultural milieu (Leszszawski-Schwerk 83, 12122). Her case is an exception, as she was neither a native speaker of Ukrainian, nor otherwise affiliated with the Ukrainian national movement.
} 
next year (seen from Hrushevs'kyi's correspondence). ${ }^{33}$ Interpreting the courses not by the criteria established by the organizers, but as a reaction to the intense demands for popular science in Galicia, can provide an alternative explanation. The failure to integrate the NTSh opposition in the summer course program meant that several disciplines and certain distinguished scholars were excluded. ${ }^{34}$ Therefore, however important the courses were regarding other accomplishments, they did not satisfy the demands of the public or the demands of the opposition. On the contrary, the inner crisis and public criticism of the NTSh intensified (Pavlyk). The summer courses in Lviv corresponded with the larger project of setting "Ukrainoznavstvo" ("Ukrainian studies") as the research agenda of the NTSh, which sought to bring unity to Ukrainian "national science" with special emphasis on the humanities. For several members of the Ukrainian scientific community in Lviv, however, public dissatisfaction and disappointment with the NTSh agenda were reasons to retreat from the NTSh, and this contributed to institutional diversification. ${ }^{35}$

\section{INVENTING A PLATFORM FOR UKRAINIAN POPULAR SCIENCE}

Hrushevs'kyi's solo run of summer courses in Lviv aggravated the smoldering crisis in the NTSh. Therefore, shortly after the summer school project, efforts were made to establish the Petro Mohyla Society for Ukrainian Scientific Lectures (Tovarystvo ukrains'kykh naukovykh vykladiv im. Petra Mohyly). Recent studies of this society consider its creation to have been a direct effect of the summer courses held in Lviv, and a step toward the establishment of a Ukrainian university (Hertsiuk 368-69; Kril' and Leshkovych 431). While this point might be valid in terms of a history of ideas, it is clear that it represented a rupture between leading local Galician scholars and Hrushevs'kyi's group and its adherents. Indeed, disagreements regarding popular science and the exclusion of several scholars and topics provoked a separate institutionalization of a part of the former group. The opposition to the NTSh emerged at the beginning of

33 Lystuvannia Mykhaila Hrushevs'koho 55-56. The patron Chykalenko was particularly impressed because his three participating children considered the event a success.

34 Dilo, 12 June 1904, p. 2.

35 Medical professionals and law scholars departed from the NTSh to found their own associations. The Society of Ruthenian Doctors was initiated in 1908 and established in 1910 (AVA Inneres MdI Allgemein 19045/1908; 25-littia ukrains'koho likars'koho tovarystva); the Society of Ukrainian-Ruthenian Lawyers was established in 1909 (Pravnychnyi vistnyk, vol. 1, no. 1, 1910, p. 58). 
1905, and its members formed the Mohyla Society in December 1906 (Ivan Puliui 326).

Due to bureaucratic issues, the Mohyla Society started its activity only in 1909 (Protokoly zasidan' 163-64). The Mohyla Society considered itself a "people's university" 36 and organized regular public lectures on various topics between 1909 and 1914. The work of the Mohyla Society was initiated by literary scholar Kolessa, geographer Rudnyts'kyi, anthropologist Rakovs'kyi, mathematician Volodymyr Levyts'kyi (18721956), philologist Illia Kokorudz (1857-1933), and historian Stepan Tomashivs'kyi (1875-1930). ${ }^{37}$ All of the above, except Kokorudz, were part of the younger generation of Ukrainian scholars and scientists, some of them had even studied under Hrushevs'kyi. The Mohyla Society did not exclude any subjects and was generally open to "all kinds of popular knowledge and culture" and lecture topics. ${ }^{38}$ When it was necessary to set priorities, the board favoured humanities related to Ukraine and natural sciences (Protokoly zasidan' 233). The goal was to extend the mission of science and scholarship in the Ukrainian language. They favoured a national mission over an institutional mission, similar to the university extension program in Vienna. ${ }^{39}$

The Mohyla Society operated close to the idea of "organic work," as it considered some of their desired clientele to be "multipliers," e. g., persons who taught in Prosvita reading rooms in the villages and would attend the lectures to broaden their knowledge for this purpose. As Rudnyts'kyi put it, the society itself did not plan to "go to the villages," but its listeners would (Protokoly zasidan' 167). In this view, (scientific) knowledge was expected to diffuse from the cities into the countryside. Therefore, the Mohyla Society was able to attract more conservative "narodovtsi" (Protokoly zasidan' 166). The first general assembly of the Mohyla Society, in 1909, led to a substantial growth of members ready to contribute to regular lecture programs. The members were not professional popularizers, such as those Andreas Daum describes in his monograph on German popularization of science, but primarily teachers (middle school teachers, university professors, "Privatdozenten"). As several members from provincial cities

36 Dilo, 26 Oct. 1909 , p. 2.

37 Law scholar Stanislav Dnistrians'kyi took part in organizing the Mohyla Society in 1905 but performed only as a lecturer later on. During the inaugural meeting, a certain Fr. Dr. Zhuk was elected deputy head, but he never joined the society (Protokoly zasidan' 163). On Kokorudz, see Kachkan; on Tomashivs'kyi, see Khalak; on Levyts'kyi, see Bobyk et al.

38 "Zvernennia do ukrains'koi intelihentsii pro spivpratsi" ("Appeal to the Ukrainian Intelligentsia for Collaboration"), 1914, TsDIAL, f. 736, op. 1, spr. 6, ark. $1 \mathrm{zv}$.

39 For lists of the Mohyla Society's members, see TsDIAL, f. 736, op. 1, spr. 5. 
joined the Mohyla Society, a plan to expand the concept of the Ukrainian "people's university" also took shape and was realized in small steps.

From an organizational perspective, the Mohyla Society's beginning was troublesome. The Habsburg Monarchy acted as a "co-operative empire" toward several Ukrainian national associations, such as the NTSh and the Prosvita, by granting them regular subsidies (Osterkamp; Rohde, "Galizische"). The Mohyla Society was not supported in this way, and several applications for government funding failed. The society did not pay the lecturers an honorarium and could reimburse only travel costs in 1909; it was therefore worried about support from the scholarly community. ${ }^{40}$ The Mohyla Society did not earn a profit, especially not in the provinces. Sometimes the local organizers had to pay for the lecture premises themselves, even when the lectures were well attended. Accordingly, the Mohyla Society could finance its growing number of activities only through membership fees. It received only small donations from other Ukrainian organizations. While popular scientific publications were planned, they could not be realized due to financial obstacles (Protokoly zasidan' 220).

The minutes of the first assemblies, and reports collected in the middle of 1912, offer insight into the topics presented and number of attendees at the Mohyla Society lectures. Unfortunately, not all of the material on the society has been preserved (or made available yet), so that data can support only exemplary points. The Mohyla Society collected data on visitors, but not on their nationality, religion, or individual language preferences, so there is no way to evaluate these aspects.

Table 1. First lectures organized by the Mohyla Society in 1909.41

\begin{tabular}{|l|l|c|}
\hline Lecturer(s) & Topic(s) & Visitors \\
\hline $\begin{array}{l}\text { Oleksandr Kolessa, Stepan } \\
\text { Rudnyts'kyi }\end{array}$ & Literature, Geography & 289 \\
\hline Volodymyr Okhrymovych & Galician National Statistics & 245 \\
\hline Osyp Makovei & Ukrainian National Culture (Bukovyna) & 165 \\
\hline Ivan Rakovs'kyi & Darwin and Darwinism & 300 \\
\hline
\end{tabular}

The first Mohyla Society lectures took place during February 1909 (Table 1). The organizers intended to provide a broad variety of subjects and to discuss current topics, such as politically relevant Galician statistics, or Darwinism, both of which had lately entered Ukrainian discourses in

\footnotetext{
40 Dilo, 26 Oct. 1909, p. 2.

41 Protokoly zasidan' 171. Even though these numbers appear to be rounded, the numbers in the minutes match the income from admission fees, so they appear trustworthy, after all.
} 
Galicia. ${ }^{42}$ The number of visitors to the lectures on natural science is particularly surprising given the dominance of the humanities in Ukrainian popular nationalism, and this finding should be discussed in a broader context. In the roughly three and a half years, until July 1, 1912, 407 lectures were organized all over Galicia, including 42 on geography, 18 on "medicine and hygiene," and 52 on "natural sciences," 43 categories that show the fluidity of the classifications in the given period. With a few exceptions, lectures in these fields were titled in popular, commonly understandable ways, as these examples illustrate: "The Secrets of Nature," "About the Air," "The Sense Organs," "On Nutrition," "On Volcanos," "Sleep-with demonstration." 44 Many of the lectures were illustrated with a growing collection of dia-positives (positive photographic slides or transparencies), because not only the topic but also the technique of presentation promised to draw a broader audience (Protokoly zasidan' 216). One of the first actions of the newly formed Mohyla Society board in 1909 was to buy a sciopticon (an image projector) "without which it is not possible to popularize many sciences now." 45 Furthermore, certain lecturers, such as Rakovs'kyi and Rudnyts'kyi, proved to be major attractions, so that the natural sciences turned out to be the most popular subjects. ${ }^{46}$ Likewise, the organizers of the Uniwersytet ludowy ("People's University") realized after their first year of intense activity that natural sciences would generally attract more visitors than social sciences or humanities - a conclusion reflected in the attendance at lectures in Vienna as well. ${ }^{47}$ This finding is impressive considering the predominance of "Ukrainoznavstvo" ("Ukrainian studies") in the historical research of Ukrainian science in Lviv (Homotiuk). It appears, then, that the indifference toward the natural sciences reflected in the summer courses in Lviv was largely a product of Hrushevs'kyi's concept of "national science" and did not reflect popular demand. Because they attracted so many visitors, lectures on the natural sciences were no less important for community

\footnotetext{
42 For the relevance of the statistics, see Rohde, "Local," 197-205.

43 The numbers presented in the report tend to vary insignificantly because the preserved report was only a draft. The report sent to the Ministry of Education in Vienna was discarded. AVA Unterricht UM allg., Fasz. 3413.

44 TsDIAL, f. 736, op. 1, spr. 3, ark. 39-40, 43.

45 Dilo, 26 Oct. 1909, p. 2.

46 To make a direct comparison, in 1909, Rudnyts'kyi's two lectures on the North Pole attracted roughly twice as many visitors as Kolessa's readings on the history of the Ukrainian language. Rudnyts'kyi: November 7 and 8, 280 and 240 visitors, respectively; Kolessa: October 31 and November 14, 120 and 150 visitors, respectively. Protokoly zasidan' 179.

47 Wiedza dla Wszystkich, vol. 1,1899, p. 17.
} 
building than those on the humanities, as the former served the "ritualization of education" in a national framework (Hüchtker 201).

From a spatial perspective, some places displayed more interest than others in a single subject. For example, lectures on medicine and hygiene were comparatively more highly attended in provincial regions, and in three villages that hosted lectures for the first time in 1912, than in Lviv. ${ }^{48}$ Thus, the local organizers expressed interest in educating peasants with the types of knowledge they could practically apply. In Lviv, no lectures on law or pedagogy took place, whereas these were provided in smaller cities. $^{49}$ In those cases, the individual interests of the local lecturers and organizers offer plausible explanations for the lecture topics chosen.

Despite the stunning start, the Mohyla Society's board was shortly thereafter disappointed in the popularity level of their lectures. Between the beginning of the lectures in 1909 and the reports issued in 1912, there were almost 10,000 attendees in Lviv, which reflects an average of 91 visitors to each of the 108 lectures provided. In Lviv, the number of attendees started to decline in late 1909. Alternative programs in several clubs, as well as other cultural offerings in Lviv, might have been responsible. ${ }^{50}$ As there is no nationality data identified for the attendees of the Uniwersytet ludowy, the impact of this institution on the attendance rate for the Mohyla Society's lectures can only be guessed. From a nationalist's perspective, the declining attendance of the Mohyla Society's lectures was a subject of national indifference. Therefore, the Mohyla Society's board promoted the idea of a segregated national public in the transcultural contact zone called Lviv without questioning their own organization, lecture program, or teaching methods. Furthermore, they barely considered criticism from within the national movement. After commenting on the first months of lectures, Dilo, the most influential "narodovtsi"-newspaper, largely ignored or even criticized the society's activities (Protokoly zasidan' 187). Even though the Mohyla Society reconciled with Dilo, which started to regularly publicize all the lectures in Lviv in 1910, the board was still unsatisfied with the attendance rates and blamed the university students and the high school students for the indifference to the lectures. As a result, the board turned to the teachers with a request to motivate their students to attend the lectures. As young people were offered a discount on the entrance fees, in early 1912 all branches were asked to report on the age of the visitors in order to evaluate the success of this measure (Protokoly zasidan' 216). This idea seemed to be successful from a general

48 TsDIAL, f. 736, op. 1, spr. 3, ark. 15; reports of the local groups, spr. 29, ark. 1.

49 TsDiAL, f. 736, op. 1, spr. 3, ark. 15; reports of the local groups, spr. 29, ark. 1.

50 TsDIAL, f. 736, spr. 29, ark. 1 zv.; table 2. 
perspective. In Lviv, the data indicated that the number of young attendees ranged from $48 \%$ to $94 \%$ (Table 2) except for the last lecture. Either the topic-Lviv churches and their artwork-was not interesting for young people or the time might have been an obstacle. ${ }^{51}$

The Mohyla Society reports in early 1912 documented the worst visitor statistics overall in Lviv; the indifference of the older generation was suggested to be responsible for the low visitor attendance. The low attendance at the lectures provoked debates among the leading members of the Mohyla Society regarding alternative ways of teaching. Shortly afterward, guided city walks and museum tours led by Ukrainian experts were introduced. ${ }^{52}$ This concept was not generally new and might have been directly inspired by analogous events organized by the Mickiewicz Society (Hüchtker 206). Three museum tours attracted a total of 386 visitors and were therefore considered to be popular events. ${ }^{53}$ The ethnographer Volodymyr Shukhevych (1849-1915) led one of these tours in the Lviv ethnographic museum. ${ }^{54}$ He was familiar with the museum and was a well-established member of the Galician "narodovtsi" intelligentsia (Karpenko). Four similar tours, in which churches were visited during art history courses, were attended by only 134 visitors in total. ${ }^{55}$

\section{CO-OPERATION AND EXPANSION}

It is hardly surprising that student associations, professional interest groups, and academic societies organized lectures at their regular meetings. ${ }^{56}$ The Prosvita and local associations in Lviv turned to the

\footnotetext{
51 As Olena Berezhnyts'ka-Budzova recalled in 1939, many members of the Kruzhok could not take part in the evening activities in early twentieth century because it was considered inappropriate in conservative Lviv for young women to be out in the evening (Nova Khata, vol. 15, no. 6, 1939, p. 3).

52 Protokoly zasidan' 218. Furthermore, alternatives to classic lectures were considered. Franko, who did not participate in the society's activities otherwise, agreed to read from his famous poem "Moisei" ("Moses"; TsDIAL, f. 736, op. 1, spr. 3, ark. 40).

53 TsDIAL, f. 736, op. 1, spr. 3, ark. 35.

54 Dilo, 18 May 1912, p. 5; 15 June 1912, p. 7.

55 TsDiAL, f. 736, op. 1, spr. 3, ark. 35; Dilo, 4 May 1912, p. 5.

56 Cf. for example Rus'ke tovarystvo pedahohichne as the central association of Ukrainian teachers (Uchytel', vol. 14, 1904, p. 25), which included several members of the Mohyla Society and also frequently proposed the initiation of lectures in the provinces (Uchytel', vol. 15, 1905, p. 300. Prosvita branches and people's houses ("narodni domy") were free to engage in popular scientific activities at a local level,
} 
Mohyla Society to initiate lectures for their respective audiences, clearly showing that there was a broad demand for such lectures in other Ukrainian national associations. The Mohyla Society initially had to dismiss the proposals because it lacked the necessary resources, but agreed to adjust the programs if possible. ${ }^{57}$ Co-operation intensified in 1910 , and the Mohyla Society heightened its efforts to organize lectures for Prosvita reading rooms in rural areas and for other associations in Lviv. ${ }^{58}$ Two years later, stable local groups were formed that organized a highly successful lecture series. ${ }^{59}$

The prerequisite for an expansion of the Ukrainian "people's university" was the formation of local committees that were dedicated enough to carry out the organizational tasks by themselves. Consequently, the success of the plan to expand all over eastern Galicia depended on mobilizing national activists in the provinces to join the project. In early 1909, the Mohyla Society was still struggling with this expansion, as only four local committees had been formed. ${ }^{60}$ The expansion could not proceed by establishing regular branches of the Mohyla Society due to bureaucratic issues, which were interpreted as chicanery by the local Galician authorities. The expansion was formalized only in the standing rules accepted in 1912 (Protokoly zasidan' 187, 206; AVA Inneres MdI Allgemein 2188/1912). The interest in expansion in the provinces soon started to flourish. By mid-1912, sixteen branches in east-Galician cities and three local committees in villages had been established.61

as long as they could provide financial and personal resources. However, public lectures were usually dependent on individuals taking the initiative (Holovats'kyi 18-22). The bureaucratic effort to organize events, which had to be in the official framework of an association's standing rules, was not to be underestimated. Otherwise, local authorities could forbid events based on the law of assemblies or the law regarding associations (Rohde, "Innerimperiale" 193).

57 Zoria, an association of Ruthenian-Ukrainian craftsmen and industrialists organized a short series of history lectures at the beginning of 1909, supported by the Mohyla Society (Dilo, 3 Mar. 1909, p. 3; 26 Oct. 1909, p. 2).

58 Dilo, 26 Jan. 1911, p. 3.

59 TsDIAL, f. 736, op. 1, spr. 4, ark. 1.

60 Dilo, 26 Oct. 1909, p. 2.

61 TsDIAL, f. 736, op. 1, spr. 3, ark. 2. 
Table 2. Attendees at Mohyla Society lectures in Lviv and Przemyśl/Peremyshl in the beginning of 1912.

Lviv

\begin{tabular}{|l|c|c|c|c|c|}
\hline Date (time) & \multicolumn{1}{c}{ Men } & Women & \multicolumn{1}{c}{ Old } & \multicolumn{1}{c|}{ Young } & Total \\
\hline 04.02. & 43 & 16 & 7 & 52 & 59 \\
\hline 11.02. & 26 & 7 & 6 & 27 & 33 \\
\hline 18.02. & 44 & 13 & 7 & 50 & 57 \\
\hline 25.02. (12.00) & 30 & 7 & 9 & 28 & 37 \\
\hline 25.02. (16.00) & 52 & 15 & 19 & 48 & 67 \\
\hline 03.03. & 17 & 9 & 4 & 22 & 26 \\
\hline 10.03. & 79 & 42 & 37 & 84 & 121 \\
\hline 17.03. & 35 & 44 & 29 & 60 & 89 \\
\hline 24.03. (16.00) & 62 & 10 & 4 & 68 & 72 \\
\hline $24.03 .(19.00)$ & 22 & 4 & 26 & 0 & 26 \\
\hline
\end{tabular}

\section{Przemyśl/Peremyshl}

\begin{tabular}{|l|c|c|c|c|c|}
\hline 21.01. & 106 & 57 & 35 & 128 & 168 \\
\hline 28.01. & 148 & 96 & 85 & 189 & 244 \\
\hline 04.02. & 174 & 124 & 87 & 211 & 298 \\
\hline 11.02. & 201 & 137 & 100 & 238 & 338 \\
\hline 25.02. & 115 & 78 & 39 & 154 & 193 \\
\hline
\end{tabular}

The first local committee of the Mohyla Society was formed in Przemyśl/Peremyshl in 1909, attracting up to 370 visitors during the first lecture series in February. The Mohyla Society also initiated a "popularscientific library" in Peremyshl with several thousand volumes available to the public, which was administered by the local committee. ${ }^{62}$ However, the society did not account for extra expenses, so one can conclude that local activists did not receive an honorarium for running the library, and that the above initiative of a "popular-scientific library" most probably included the pre-existing book collections. In contrast to Peremyshl, in Lviv, several Ukrainian associations-the NTSh, the Prosvita, and the Narodnyi dim (People's Home), to name the largest-organized and ran public libraries (Kupanets'). However, the Mohyla Society did not see the necessity to open and sponsor its own library in the Galician capital.

The demand for public lectures was considerably higher and more consistent in the provinces than in Lviv. From 1909 to July 1912, 47

62 Dilo, 26 Oct. 1909, p. 2. 
lectures took place in Lviv and the provinces, with an average of 247 visitors. Cities other than Lviv had fewer lectures due to the later start of the Mohyla program and other inconsistencies, but had a considerably higher number of visitors. The 56 lectures in Stanislaviv/Stanislawów (today's Ivano-Frankivsk), for example, had an average of 117 visitors between 1909 and early 1912. Even in the small town of Pukiv (in today's Ivano-Frankivska Oblast), 195 guests on average attended the four lectures conducted in 1912.63

The reports detailed in Table 2 categorized visitors by age and gender. The categories were not defined, but "young" was obviously used to distinguish students. As the statistics show, the visitors included many "young" and many "female" individuals. These statistics are not limited to the given examples; they are similar in all preserved reports. In Przemyśl/Peremyshl, the lectures took place in the halls of the Ruthenian Private Lyceum for Girls, which presumably accounts for the relatively high number of young female visitors (Table 2). In the school years from 1910 to 1914 , the total number of students in the Ruthenian Private Lyceum for Girls ranged between 200 and 220, all of them with Ukrainian as a native language. ${ }^{64}$ The link between female emancipation and popular education is thus emphasized. Considering these numbers, women contributed significantly to the thriving of popular education by attending the lectures and paying the fees. Had they not taken part in this enterprise, the expansion of the Mohyla Society and the mobility of lecturers would not have been possible. On the other hand, there were no women among the lecturers during the period under consideration. Female lecturers were mostly limited to associations of women, such as the Kruzhok or its followup organization, the Soiuz Ukrainok.

\footnotetext{
63 TsDIAL, f. 736, op. 1, spr. 3.

64 Sprawozdanie c. $k$. Rady szkolnej krajowej 27; Zvit dyrektsyi 49. Furthermore, the state gymnasium with the Ukrainian language of instruction had between 752 and 901 male students in the years 1910-14 (Pakholkiv 515). While there was a considerably higher number of middle school students with the Ukrainian native language in Lviv, Lviv had more cultural offerings than Peremyshl, which might further explain the popularity of the Mohyla Society lectures in Peremyshl. The Academic Gymnasium had between 639 and 614 students, and its nearby branch had between 707 and 764 students in the years 1910-12 (Sprawozdanie c. k. Rady szkolnej krajowej 12).
} 


\section{POPULAR NATIONALISM}

The Mohyla Society lectures from 1909 to 1912 popularized the history of the Cossacks and the term "Ukraine," asking critically, "Are we Ruthenians or Ukrainians?" 65 The lectures also discussed cultural connections between Galicia and other parts of Ukraine, and propagated a Ukrainian literary canon, a national folklore, and national customs. ${ }^{66}$ Many of these topics were already present in the popular culture. However, the lectures served the objective of Ukrainian studies ("Ukrainoznavstvo"67), which was to propagate a canon of general knowledge of Ukrainian culture and export it to the provinces. As the numbers suggest, Ukrainian studies were much more successful in the provinces than in Lviv.

Popular nationalism brought forward by elites is a common feature in the histories of national movements (Hroch). The latest research tends to interpret this as a struggle with national indifference, whereas this indifference has to be considered to be part of a nationalist belief system (Judson, Guardians; Whitmeyer; King; Zahra, "Imagined"; Zahra, Kidnapped). In Lviv, indifference toward "Ukrainoznavstvo" seemed to grow on the part of the audience, as the numbers suggest that lectures on natural sciences were considerably better attended. Lectures on geography and anthropology were exempt from this trend, likely because they popularized lesser known subjects and tended to apply "hard science" to national issues, especially since 1910 .

Rudnyts'kyi was the single most active lecturer in this early period until mid-1912, during which he offered twenty-three lectures. ${ }^{68}$ Even when the general number of visitors declined severely, Rudnyts'kyi's lectures usually attracted over a hundred visitors. He was also active in popularizing Ukrainian geography in Rus'ke tovarystvo pedahohichne and published important work on teaching that discipline (Rudnyts'kyi, Nynishna heohrafiia). Regarding the link with Vienna, it is noteworthy that his former teacher, geographer Albrecht Penck, was one of the first lecturers in the university extension program in the imperial capital, and an important popularizer of geography in general (Stifter, "Universität und Volksbildung" 03/3-03/4; on Penck, see Henniges). Rudnyts'kyi's first lectures in 1909 were dedicated to general matters of geography without a national or specific connotation (e.g., the geography of the North Pole, or

\footnotetext{
65 TsDIAL, f. 736, op. 1, spr. 3, ark. 44.

66 TsDIAL, f. 736, op. 1, spr. 3, ark. 38zv-44zv.

67 The term was used formally only in 1914 by the Mohyla Society (Protokoly zasidan' 233).

68 TsDIAL, f. 736, op. 1, spr. 3, ark. 43.
} 
volcanoes). In 1910, the same year he published his first book on Ukrainian national territory, he started to lecture regularly on (western) Ukrainian national borderlands (Rudnyts'kyi, Korotka geografiia Ukrainy. Chast' I). His first series of four lectures was conceptualized as a "systematic course." 69 Even though Rudnyts'kyi became a "Privatdozent" at the University of Lviv in 1908, he was not able to propose a course on the geography of Ukraine until 1913 ("Osnovni daty"). Rudnyts'kyi's lectures on Ukrainian geography were not a tool to extend the official mission and academic programs of the university. Nevertheless, they allowed students to concentrate on a subject that was not covered by the official curriculum. This plausibly helped to attract those students majoring in geography who wanted to learn specifically about Ukraine. The board of the Mohyla Society planned to increase the number of such courses as soon as the financial situation would allow. ${ }^{70}$

In 1911, Rudnyts'kyi introduced his ideas regarding the influence of geography on the "development of nations" and presented a specialized lecture on Ukrainian anthropogeography to his audience. ${ }^{71}$ These lectures outlined a crucial element of Ukrainian popular nationalism, which was highly propagated during World War I (Hausmann). Due to these public lectures, the local intelligentsia was introduced to Rudnyts'kyi's ideas several years prior to the publication of his monographs. His activity was crucial for the popularization of geography in the Ukrainian language and for the popularization of the geography of Ukraine in general.

Rakovs'kyi was the most dedicated popularizer of evolutionary theories and racial anthropology in the Galician Ukrainian community. The fact that Rakovs'kyi's lecture on Darwin and Darwinism, presented in February 1909, enjoyed the highest attendance of all the lectures in Lviv is particularly important. The dissemination of Darwin's works and ideas was made possible by many translations, and these ideas influenced other cultural works. In Galicia, Darwin's works were widely accessible, e.g., through literary works by Leopold von Sacher-Masoch and Franko (Schümann). These topics were especially interesting to young intellectuals; for example, the student organization Akademichna hromada

69 Dilo, 26 Jan. 1911, p. 3.

70 Dilo, 26 Jan. 1911, p. 3. This idea was realized when lectures on Taras Shevchenko were offered.

71 Protokoly zasidan' 204; TsDIAL, f. 736, op. 1, spr. 3, ark. 43. Rudnyts'kyi gave eight general lectures on the geography of Ukraine and one on Ukrainian anthropogeography. This would become the topic of the second volume of his work on Ukrainian national territory (published in 1914). The lectures organized by the Mohyla Society, therefore, became a way to introduce very recent and unpublished research to the public. 
held a forum with several lectures on evolutionary biology in late June 1909. ${ }^{72}$ Rakovs'kyi summarized the theories and also translated ongoing international debates ("Iubylei"; "Borot'ba"). He regularly lectured on these subjects in the framework provided by the Mohyla Society. ${ }^{73}$ As he worked closely with anthropologist Fedir Vovk, Rakovs'kyi popularized their common work in Galicia through lectures on Ukrainian anthropology. ${ }^{74}$ The most important contribution Vovk made to Ukrainian popular nationalism was the justification of a separate Ukrainian anthropological type by the means of anthropometrical data, as Rudnyts'kyi pointed out in his anthropogeographic works (Wowk; Rudnyts'kyi, Korotka geografiia Ukrainy. Chast' II). These subjects were also not part of the usual university programs, as anthropology was not formally established until 1911 at Lviv University, and Ukrainian scientists were not part of the new institute (Tarnavs'kyi).

In the years following 1909 , subjects related to popular nationalism became increasingly more prominent. Taras Shevchenko was a leading writer, artist, and public and political figure who became of key importance during one of the most integrative moments of the Ukrainian national community in general and for the Galician "narodovtsi" (populists) in particular. The Shevchenko jubilees in 1911 (fiftieth anniversary of his death) and 1914 (one hundredth anniversary of his birthday) were important events all over eastern Galicia (Struve 370-75). The Mohyla Society had already offered a series of lectures on the life and work of Shevchenko in 1911, and was planning a broader program for the coming years (Protokoly zasidan'196, 200). In 1913 and 1914, sixteen lectures on Shevchenko and his works were given in Lviv alone. They replaced the natural sciences and other subjects to a certain extent; therefore, they addressed a different clientele. For the celebration of the Shevchenko anniversary in 1914, the Mohyla Society encouraged lecturers to go to small towns and villages. ${ }^{75}$ Hence, in this case, expansion and popular nationalism went hand in hand.

\footnotetext{
72 Dilo, 19 June 1909, p. 4.

73 TsDIAL, f. 736, op. 1, spr. 6, ark. 1.

74 While the understanding of anthropology was still highly debated in the given period, Rakovs'kyi defined it as "science about man, especially about human races" ("Iubylei" 153). See also Halushchyns'kyi. The spread of Darwinism in Ukrainian cultural and academic discourse still needs to be researched at a more detailed level, and the influence of Darwinism on Ukrainian thought should be compared to a similar influence on German, Russian, and Polish cultural debates.

75 TsDIAL, f. 736, op. 1, spr. 6.
} 


\section{CONCLUDING REMARKS}

In contrast to claims of the national narratives, the offering of Ukrainian popular science lectures to the Galician population was not an immediate national success. It was an intense struggle that lacked resources and faced what activists continuously considered to be national indifference toward the project. Sources show that the Mohyla Society and its lecturers operated from a nationalist standpoint, with most lecturers and audiences participating in an endeavour to make science an enjoyable, entertaining public event that could help to nationalize the respective groups. Crucial to this project were the mostly unpaid efforts of the popularizers. ${ }^{76}$ Without female interest groups and female audiences, the dynamics and extent of popular scientific lectures would have been considerably different, as shown by the initiatives of the Kruzhok ukrains'kykh divchat, the female participants in the Lviv summer courses in 1904, and the lectures of the Mohyla Society. Even though women did not serve as lecturers, this case study shows that it was the public, not the scholars and scientists, that provided the early initiatives to popularize science in Galicia.

In the early 1900s, the imperial environment of the Habsburg Monarchy and the transnational situation in Galicia provided fertile grounds for the popularization of science. This had little to do with a simple diffusion of concepts, as circulating ideas were adapted to the specific situation of the Ukrainian national community. The introduction of the Shevchenko cult and "Ukrainoznavstvo" (Ukrainian studies), which proved to be influential despite the severe criticism from and the diversification of the Ukrainian institutional landscape in Lviv, illustrate this point. The Mohyla Society partially adopted "Ukrainoznavstvo," but when it introduced a canon of shared knowledge to its audiences, the natural sciences were present as well. Sociability and regular meetings were no less important for building a community. This point can only be a theoretical assumption regarding the visitors to the lectures organized by the Mohyla Society, but it is documented and proven for its leading members ${ }^{77}$ and for the summer courses held in Lviv in 1904. By participating in the courses offered by the Mohyla Society, the attendees helped to create a new social space.

76 For the importance of unpaid contributors to scientific community building and the NTSh, see Rohde, "Local."

77 Co-operation between the Mohyla Society founding members, such as Kolessa, Dnistrians'kyi, and Rudnyts'kyi, on several later occasions also deserves mention, e.g., the inner politics of the NTSh during its crisis in 1913 (Hrytsak; Vynar) and the founding of the Ukrainian Free University after World War I (TsDAVO, f. 3859c, op. 1, spr. 139, ark. 14-15). 
The mobility of lecturers and the local supporters enabled the Mohyla Society to export its concept to the countryside. However, such expansion faced several issues in its early history, possibly due to national indifference. This was more obvious in the case of the trial run to expand to Chernivtsi in January 1913. The local organizer considered the lecture a "fiasco" because the "Chernivtsi public was on strike and did not go to a Uniate-Galician [uniiats'ko-halitsyians'kyi] lecture," pointing out the religious component of the differences between the Ruthenian-Ukrainian populations in Galicia and Bukovina. Tellingly, the local organizer also had to pay most of the expenses himself, and ultimately stepped back from the idea of continuing the co-operation. ${ }^{78}$ The role of Lviv as a centre for the Ukrainian community in Galicia was nevertheless promoted by strengthening the exchange between groups, associations, and individuals who comprised the eastern Galician intelligentsia. Such practices were not fundamentally new, and were also followed by the Prosvita, but they raised the process to a new level and included other locales. From an imperial perspective, this contributed to the decentralization of science. In contrast to a similar project in Vienna, the Mohyla Society did not extend the functions of Lviv University, but tried to be an alternative source of education with respect to language and content. The growing number of projects was brought to a sudden end by the outbreak of World War I. Using its resources and personnel structures, however, the Mohyla Society contributed to the establishment of the Secret Ukrainian University, which was active in Polish Lwów between 1921 and 1925. ${ }^{79}$

This paper supported the "artificial distinction between 'popular science' and 'science proper,'” because this distinction was negotiated for the Ukrainian community in the examined context and was important to the actors involved (Topham, "Rethinking" 1). Jan Surman recently argued for the invention of Ukrainian scientific terminology because "in the Ruthenian-Ukrainian case science was made by its popularizers and language activists, and the distinctions between genres of scientific literature were blurred" ("Science" 263). The same was true for the lecturers, as they were not professional mediators but scholars or teachers who shared the impetus to popularize their respective disciplines. Several views on the prospective audience (as discussed during sessions of the Mohyla Society board) showed that there was no clear concept or understanding of the demands of the "lay public" that the Mohyla Society sought to educate, except for the need to offer lectures in the Ukrainian language and to provide an educational supplement for the youth by

78 TsDIAL, f. 736 , op. 1 , spr. 11 , ark. 23.
79 TsDIAL, f. 310 , op. 1 , spr. 6. 
teaching academic content on Ukrainian matters that was not available at existing universities.

\section{Works Cited}

\section{Primary Sources (Archives)}

Austrian State Archives, Vienna, Allgemeines Verwaltungsarchiv (= AVA): Ministerium des Innern; Ministerium für Cultus und Unterricht.

Central State Archive of Supreme Bodies of Power and Government of Ukraine (= [Tsentral'nyi derzhavnyi arkhiv vyshchykh orhaniv vlady ta upravlinnia Ukrainy] TsDAV0), fond 3859c: Ukrains'kyi vil'nyj universytet v Prazi.

Central State Historical Archives of Ukraine Lviv (= [Tsentral'nyi derzhavnyi istorychnyi arkhiv Ukrainy u m. L'vovi] TsDIAL), fond 309: Naukove tovarystvo im. Shevchenka; fond 310: Ukrains'kyj universytet u L'vovi; fond 319: Tsentral'ne Ukrains'ke Natsionalistychne Tovarystvo "Soiuz Ukrainok," m. Lviv; fond 400: Ukrains'ka zahal'na rada; fond 736: Tovarystvo ukrains'kykh naukovykh vykladiv im. Petra Mohyly.

State Archive of Lviv Oblast (= [Derzhavnyi arkhiv L'vivs'koi oblasti] DALO), fond 298: Tovarystvo prykhyl'nykiv ukrains'koi nauky, literatury i shtuky.

\section{Primary Sources (Periodicals)}

Dilo. Lviv.

Literaturno-naukovyi vistnyk (= LNV). Lviv.

Nova khata. Lviv.

Pravnychnyi vistnyk. Lviv.

Uchytel'. Lviv.

Wiedza dla Wszystkich. Lwów.

\section{Primary Sources (Other published works)}

25-littia ukrains'koho likars'koho tovarystva i medychnoi hromady. Lviv, 1935. Reprinted by Ukrains'ke likars'ke tovarystvo pivnichnoi Ameryky/Medychnyi arkhiv i biblioteka, Chicago, 1975.

Doroshenko, Volodymyr. "Ivan Franko." Spohady pro Ivana Franka, edited by Mykhailo Hnatiuk, Kameniar, 2011, pp. 553-64.

---. "Ivan Franko v moikh spohadakh." Spohady pro Ivana Franka, edited by Mykhailo Hnatjuk, Kameniar, 2011, pp. 548-52.

Franko, Ivan. "Deshcho pro nashu presu." $L N V$, vol. 31, no. 7, 1905, pp. 62-71, 76-81.

---. Zibrannia tvoriv u p"iatydesiaty tomakh. Vol. 50: Lysty (1895-1916), Naukova dumka, 1986. 
Grushevskii, M. S. (Mykhailo Hrushevs'kyi). "Razvitie ukrainskikh izuchenii v XIX v. i raskrytie v nikh osnovnykh voprosov ukrainovedeniia." Ukrainskii narod v ego proshlom $i$ nastoiashchem, edited by Mikhail Grushevskii et al., Obshchestvennaia Pol'za, 1914, pp. 1-37.

Halushchyns'kyi, Ivan. Darvinizm abo nauka o pokhodzheniu. Rus'ka Rada, 1903.

Hrushevs'kyi, Mykhailo. Nasha polityka. Materiialy do istorii konfliktu v NTSh 1913 roku. Edited by Liubomyr Vynar and Ievhen Pshenychnyi, Kolo, 2003.

Ivan Puliui (1845-1918). Lysty. Zbir, uporiadkuvannia, poiasnennia O. M. Zbozhna. Volia, 2007.

Lystuvannia Mykhaila Hrushevs'koho. Vol. 5: Lystuvannia Mykhaila Hrushevs'koho ta Ievhena Chykalenka. Edited by I. Starovoitenko and O. Todiichuk, UIT, VD "Prostir," 2010.

Pavlyk, Mykhailo. Z "Naukovoho Tovarystva im. Shevchenka” u L'vovi. Lviv, 1905.

Protokoly zasidan' Tovarystva ukrains'kykh naukovykh vykladiv im. Petra Mohyly (1906-1939 rr.). Edited by Bohdan Horbovyi, Triada plius, 2012.

Rakovs'kyi, Ivan. “Borot'ba za ideiu rozvoiu.” LNV, vol. 50, 1910, pp. 297-318.

---. "Iubylei idei rozvoiu." LNV, vol. 46, 1909, pp. 140-54.

Rudnyts'kyi, Stepan. Korotka geografiia Ukrainy. Chast' I. Drukars'ka spilka, 1910.

---. Korotka geografiia Ukrainy. Chast' II, NTSh, 1914.

---. Nynishna heohrafiia. Naukovyi dodatok do zhurnalu Uchytel', NTSh, 1905.

Sprawozdanie c. $k$. Rady szkolnej krajowej o stanie szkół średnich galicyjskich $w$ roku szkolnym 1911/1912. Lwów, 1913.

Statut tovarystva "Kruzhok ukrains'kykh divchat" u L'vovi (n. d.). Lviv.

Wowk, Fedir. "Die Ukrainer in anthropologischer Beleuchtung." Ukrainische Rundschau, vol. VI, 1908, pp. 487-93.

Zubryts'kyi, Mykhailo. "Stanovyshche rus'koi zhurnalistyky suprotyv naukovoi roboty v 'Nauk. Tovarystvi im. Shevchenka.” LNV, vol. 31, 1905, pp. 71-75.

Zvit dyrektsyi ts. k. akademichnoi himnazyi u L'vovi za shkil'nyi rik 1910/1911. Lviv.

\section{Secondary Sources}

Anderson, Benedict R. Imagined Communities. Reflections on the Origin and Spread of Nationalism. Verso, 2006.

Ash, Mitchell G., and Jan Surman. "The Nationalization of Scientific Knowledge in Nineteenth-Century Central Europe: An Introduction." The Nationalization of Scientific Knowledge in the Habsburg Empire 1848-1918, edited by Mitchell G. Ash and Jan Surman, Palgrave Macmillan, 2012, pp. 1-29.

Bensaude-Vincent, Bernadette. "A Historical Perspective on Science and Its 'Others.'” Isis, vol. 100, no. 2, 2009, pp. 359-68.

Binder, Harald. "Das ruthenische Pressewesen." Die Habsburgermonarchie 18481918. Vol. VIII: Politische Öffentlichkeit und Zivilgesellschaft. Part 2: Die Presse als Faktor der politischen Mobilisierung, edited by Helmut Rumpler and Peter Urbanitsch, Verlag der österreichischen Akademie der Wissenschaften, 2006, pp. 2091-2116. 
---. “'Galizische Autonomie'-ein streitbarer Begriff und seine Karriere.” Moravské vyrovnání z roku 1905. Možnosti a limity národnostního smíru ve střední Evropě. Sborník př́spěvku ze stejnojmenné mezinárodní konference konané ve dnech 10.11. listopadu 2005 v Brně, edited by Lukáš Fasora, Matice Moravská pro Výzkumné Středisko pro Dějiny, 2006, pp. 239-65.

Blahyi, Vasyl'. "Studentky L'vivs'koho universytetu v 1897-1914 rokakh." Visnyk LNU. Ser. ist., vol. 33, 1998, pp. 132-38.

Bobyk, Omelian, et al. "Vydatnyi ukrains'kyi matematyk i prosvitnyk Volodymyr Levyts'kyi (do 135-richchia vid dnia narodzhennia)." Matematychnyi visnyk NTSh, vol. 4, 2007, pp. 440-50.

Bohachevs'ka-Khomiak, Marta. Bilym po bilomu. Zhinky $v$ hromads'komu zhytti Ukrainy 1884-1939. Ukrains'kyi katolyts'kyi universytet, 2018.

Broks, Peter. Understanding Public Science. Open UP, 2006. Issues in Cultural and Media Studies.

Cherchovych, Ivanna. "Emansypatsiini idei vs konservatyvni praktyky: Zhinky u seredovyshchi ukrains'koi intelihentsii Halychyny." Ukrains'ki zhinky u hornyli modernizatsii, edited by Oksana Kis', Klub simeinoho dozvillia, 2017, pp. 32-51.

Daum, Andreas W. Wissenschaftspopularisierung im 19. Jahrhundert: Bürgerliche Kultur, naturwissenschaftliche Bildung und die deutsche Öffentlichkeit, 18481914. Oldenbourg, 2002.

Diadiuk, Myroslava. "Uchast' zhinok u diial'nosti Naukovoho tovarystva im. Shevchenka u L'vovi (khronikal'no-bio-bibliohrafichnyi aspekt)." $Z$ istorii Naukovoho tovarystva im. Shevchenka. Zbirnyk dopovidei i povidomlen' naukovykh sesii i konferentsii NTSh u L'vovi, edited by Oleh Kupchyns'kyi, NTSh, 1998, pp. 101-50.

Fleck, Ludwik. Entstehung und Entwicklung einer wissenschaftlichen Tatsache. Einführung in die Lehre vom Denkstil und Denkkollektiv. 9th ed., Suhrkamp, 2012.

Gordin, Michael D., and Karl Hall. "Introduction: Intelligentsia Science Inside and Outside Russia." Osiris, vol. 23, 2008, pp. 1-19.

Hausmann, Guido. "Die Kultur der Niederlage: Der Erste Weltkrieg in der ukrainischen Erinnerung." Osteuropa, vol. 64, nos. 2-4, 2014, pp. 127-40.

Henniges, Norman. "'Sehen lernen': Die Exkursionen des Wiener Geographischen Instituts und die Formierung der Praxiskultur der geographischen (Feld-) Beobachtung in der Ära Albrecht Penck (1885-1906)." Mitteilungen der Österreichischen Geographischen Gesellschaft, vol. 156, 2014, pp. 141-70.

Hertsiuk, Dmytro. “Tovarystvo ukrains'kykh naukovykh vykladiv imeni Petra Mohyly u L'vovi. Istoryko-pedahohichni aspekty diial'nosti (1908-1939 rr.)." PRACE NAUKOWE Akad. im. Jana Długosza w Częstochowie. Pedagogika, vol. XXIII, 2014, pp. 367-77.

Holovats'kyi, Ivan. Ivan Rakovs'kyi 1874-1949: Zhyttievo-bibliohrafichnyi narys. Naukove Tovarystvo im. Shevchenka, 2004.

Homotiuk, Oksana Ie. Stanovlennia i rozvytok naukovykh zasad ukrainoznavstva (90ti rr. XIX-persha tretyna XX st.). 2007. Ternopil's'kyj national'nyi ekonomichnyi universytet, Habilitation thesis.

Hroch, Miroslav. Das Europa der Nationen: Die moderne Nationsbildung im europäischen Vergleich. V\&R, 2005. 
Hrytsak, Iaroslav. "Konflikt 1913 roku v NTSh: prychyny i prychynky." Ukrains'kyj istoryk, vols. 110-15, 1991-92, pp. 319-32.

Hüchtker, Dietlind. Geschichte als Performance: Politische Bewegungen in Galizien um 1900. Campus, 2014.

Janowski, Maciej. "Galizien auf dem Weg zur Zivilgesellschaft." Die Habsburgermonarchie 1848-1918. Band VIII: Politische Öffentlichkeit und Zivilgesellschaft. 1. Teilband: Vereine, Parteien und Interessenverbände als Träger der politischen Partizipation, edited by Peter Urbanitsch and Helmut Rumpler, Österreichische Akademie der Wissenschaften, 2006, pp. 805-58.

---. Polish Liberal Thought before 1918. CEU P, 2004.

Judson, Pieter M. Guardians of the Nation: Activists on the Language Frontiers of Imperial Austria. Harvard UP, 2006.

---. The Habsburg Empire: A New History. Harvard UP, 2016.

Kachkan, Volodymyr. “Buv nevmiru sovisnym i nevtomnym': Skhodynamy zhyttiepysu Illi Kokorudza." Studii z arkhivnoi spravy ta dokumentoznavstva, vol. 4, 1994, pp. 85-91.

Kachmar, V. Za ukrains'kyi universytet u L'vovi. Ideia natsional'noi vyshchoi shkoly u suspil'no-politychnomy zhytti halyts'kykh ukraintsiv (kinets' XIX-pochatok XX st.). LDU imeni Ivana Franka, Instytut Ukrainoznavstva imeni I. Kryp"iakevycha, 1999.

Karpenko, A. A. "Rol' Volodymyra Shukhevycha v orhanizatsii ukrains'koho muzeinytstva v Halychyni." Zapysky istorychnoho fakul'tetu [Odes'kyi natsional'nyi universytet im. Mechnykova], vol. 26, 2015, pp. 85-97.

Khalak, Nadiia. "Naukove Tovarystvo im. Shevchenka v osobakh ioho vydatnykh diiachiv: orhanizatsiina pratsia Stepana Tomashivs'koho (1896-1918)." Ukrains'ka biohrafistyka, vol. 10, 2013, pp. 340-57.

King, Jeremy. Budweisers into Czechs and Germans: A Local History of Bohemian Politics, 1848-1948. Princeton UP, 2002.

Kotenko, Anton. "Galicia As Part of Ukraine: Lviv 1904 Summer School As an Attempt to Tie the Ukrainian Nation Together." Galizien in Bewegung: Wahrnehmungen-Begegnungen-Verflechtungen, edited by Magdalena BaranSzołtys et al., Vienna UP, 2018, pp. 257-75.

Kril', Mykhailo, and Nataliia Leshkovych. "Tovarystvo naukovykh vykladiv imeni Petra Mohyly (1908-1939 rr.)." Visnyk LNU. Ser. ist., vol. 46, 2011, pp. 430-52.

Kupanets', N. E. Naukovi biblioteky L'vova (1784-1939). Osobysti stanovlennia i rozvytky, formuvannia fondiv ta kolektsii. Vydavnytstvo Natsional'noho universytetu "L'vivs'ka politekhnika," 2010.

Kushnir, Vitalii. "Muzei Naukovoho tovarystva im. Shevchenka u L'vovi. Vid zasnuvannia do stvorennia pershoi zahal'nodostupnoi ekspozytsii." Narodoznavchi zoshyty, vol. 107, no. 5, 2012, pp. 824-32.

Leszczawski-Schwerk, Angelique. "Die umkämpften Tore zur Gleichberechtigung": Frauenbewegungen in Galizien (1867-1918). LIT, 2015.

Liusniak, Mariia. L'vivs'ke tovarystvo "Prosvita": u poshukakh styliu ta metodiv populiaryzatsii znan'. LDKF “Atlas," 2000.

Mudryi, Vasyl'. Zmahannia za ukrains'ki universytety $v$ Halychyni. NTSh u L'vovi, 1999. 
"Osnovni daty, fakty ta podii u zhyttiepysi akademika Stepana Rudnyts'koho." Istoriia ukrains'koi heohrafii, vol. 16, no. 2, 2007, pp. 17-18.

Osterkamp, Jana. “Cooperative Empires: Provincial Initiatives in Imperial Austria." Austrian History Yearbook, vol. 47, 2016, pp. 128-46. DOI: $10.1017 /$ S0067237816000102

Pakholkiv, Sviatoslav. Ukrains'ka inteligentsiia u Habsburz'kii Halychyni. Osvichena verstva i emansypatsiia natsii. LA "Piramida," 2014.

Pashuk, Volodymyr. Vnesok "Prosvity" u formuvannia kul'tu Tarasa Shevchenka v Halychyni. Pershi kroky (1868-1876). Instytut Ukrainoznavstva imeni I. Kryp"'iakevycha, 2014.

Raj, Kapil. "Networks of Knowledge, or Spaces of Circulation? The Birth of British Cartography in Colonial South Asia in the Late Eighteenth Century." Global Intellectual History, vol. 2, no. 1, 2017, pp. 49-66. DOI: 10.1080/23801883.2017.1332883

Raphael, Lutz. "Die Verwissenschaftlichung des Sozialen als methodische und konzeptionelle Herausforderung für eine Sozialgeschichte des 20. Jahrhunderts." Geschichte und Gesellschaft, no. 2, vol. 22, 1996, pp. 165-93.

Rode, Martin (Martin Rohde). "Naukovi kursy vakatsiini 1904." Interaktyvnyi L'viv, 2019, https://lia.lvivcenter.org/uk/events/kursy-vakacijni/. Accessed 11 Nov. 2019.

Rohde, Martin. 'Galizische Erbschaften? Das 'ukrainische Piemont' als transimperiales Projekt." Was bleibt von Galizien? Kontinuitäten-BrüchePerspektiven / What Remains of Galicia? Continuities-Ruptures-Perspectives, edited by Bohdana Patlatjuk et al., Vienna UP, 2020, forthcoming.

---. "Innerimperiale Lernprozesse? Die Nationalitätenproblematik der Innsbrucker Universität im frühen 20. Jahrhundert aus galizisch-ukrainischer Perspektive." Die Gegenwart des Vergangenen im urbanen Raum Czernowitz-Innsbruck. Projektergebnisse eines gemeinsamen Studierendenprogrammes der Universitäten Czernowitz und Innsbruck über das kulturelle Erbe im öffentlichen Raum, edited by Kurt Scharr and Gunda Barth-Scalmani, Innsbruck UP, 2019, pp. 183-204. Available on-line: https://diglib.uibk.ac.at/ulbtiroloa/download/pdf/3420254?originalFilename =true. Accessed 11 Nov. 2019.

---. "Local Knowledge and Amateur Participation. Shevchenko Scientific Society, 1892-1914." Studia Historiae Scientarum, vol. 18, 2019, pp. 165-218. DOI: 10.4467/2543702XSHS.19.007.11013

---. 'Nationale Wissenschaft' zwischen zwei Imperien. Die Ševčenko-Gesellschaft der Wissenschaften, 1892-1918. 2020. University of Innsbruck, PhD dissertation.

Schümann, Daniel. "Darwin's Migration to the East: Literary Responses to Darwinism in Multiethnic Galicia (Sacher-Masoch, Franko, Parandowski)." The Literary and Cultural Reception of Charles Darwin in Europe, edited by Elinor Shaffer and Thomas Glick, vol. 3, Bloomsbury, 2014, pp. 319-37.

Sdvižkov, Denis. Das Zeitalter der Intelligenz: Zur vergleichenden Geschichte der Gebildeten in Europa bis zum Ersten Weltkrieg. V\&R, 2006.

Stergar, Rok, and Tamara Scheer. "Ethnic Boxes: The Unintended Consequences of Habsburg Bureaucratic Classification.” Nationalities Papers, vol. 46, no. 4, pp. 575-91. DOI: 10.1080/00905992.2018.1448374 
Stifter, Christian H. "Universität und Volksbildung. Anmerkungen zu einem spannungsreichen Verhältnis." Magazin erwachsenenbildung.at, vol. 27, 2016, pp. 03/1-03/9. Available on-line: https://erwachsenenbildung.at/magazin/1627/meb16-27.pdf. Accessed 11 Nov. 2019.

---. 'Universität, Volksbildung und Moderne-die 'Wiener Richtung' wissenschaftsorientierter Bildungsarbeit." Universität-Forschung-Lehre: Themen und Perspektiven im langen 20. Jahrhundert, edited by Katharina Kniefacz et al., Vienna UP, 2015, pp. 293-316.

Strel'byts'ka, Sana M. Hromads'ko-politychna ta naukovo-publitsystychna diial'nist' Mykoly Hankevycha (1867-1931 rr.). 2015. L'vivs'kyi national'nyi universytet imeni Ivana Franka, PhD dissertation.

Struve, Kai. Bauern und Nation in Galizien. Über Zugehörigkeit und soziale Emanzipation im 19. Jahrhundert. V\&R, 2005.

Suproniuk, Oksana. "V. V. Doroshenko-Doslidnyk ukrains'koi presy: emihratsiinyi period (1944-1963)." Naukovi zapysky NU “Ostroz'ka akademiia." Istorychni nauky, vol. 11, 2008, pp. 292-300.

Surman, Jan. Habsburg Universities 1848-1918. Biography of a Space. 2012. University of Vienna, PhD dissertation. Available at http://othes.univie.ac.at/18482/1/2012-01-09 0103118.pdf. Accessed 11 Nov. 2019.

---. "Imperial Knowledge? Die Wissenschaften in der späten Habsburger-Monarchie zwischen Kolonialismus, Nationalismus und Imperialismus." Wiener Zeitschrift zur Geschichte der Neuzeit, vol. 9, no. 1, 2009, pp. 119-33.

---. "Science and Terminology In-Between Empires: Ukrainian Science in a Search for Its Language in the Nineteenth Century." History of Science, vol. 57, no. 2, 2019, pp. 260-87. DOI: 10.1177/0073275318800637

Tarnavs'kyi, Roman. Kafedra etnolohii L'vivs'koho universytetu. Klasychnyi period (1910-1947). L'vivs'kyi national'nyi universytet imeni Ivana Franka, 2016.

Taschwer, Klaus. Wissenschaft für viele. Zur Wissenschaftsvermittlung im Rahmen der Wiener Volksbildungsbewegung um 1900. 2002. University of Vienna, PhD dissertation.

Tel'vak, Vitalii, and Vasyl' Pedych. L'vivs'ka istorychna shkola Mykhaila Hrushevs'koho. Svit, 2016.

Topham, Jonathan R. "Introduction." Isis, vol. 100, no. 2, 2009, pp. 310-18.

---. "Rethinking the History of Science Popularization/Popular Science." Popularizing Science and Technology in the European Periphery, 1800-2000, edited by Faidra Papanelopoulou et al., Ashgate, 2009, pp. 1-20.

Vynar, Liubomyr. Mykhailo Hrushevs'kyi i Naukove Tovarystvo im. Shevchenka. 18921934. Kolo, 2006.

Weichlein, Siegfried. "Nationalismus und Nationalstaat in Deutschland und Europa. Ein Forschungsüberblick." Neue Politische Literatur, vol. 51, 2006, pp. 265-351.

Wendland, Anna Veronika. Die Russophilen in Galizien. Ukrainische Konservative zwischen Österreich und Rußland, 1848-1915. Verl. d. ÖAW, 2001.

Whitmeyer, Joseph M. "Elites and Popular Nationalism." British Journal of Sociology, vol. 53, no. 3, 2002, pp. 321-41. DOI: 10.1080/0007131022000000536. 
Zahra, Tara. "Imagined Noncommunities. National Indifference As a Category of Analysis." Slavic Review, vol. 69, no. 1, 2010, pp. 93-119.

---. Kidnapped Souls: National Indifference and the Battle for Children in the Bohemian Lands, 1900-1948. Cornell UP, 2008.

Zaitseva, Zinaida I. Ukrains'kyi naukovyi rukh. Instytutsional'ni aspekty rozvytku. Kinets' XIX-pochatok XX st. KNEU, 2006. 